theme 1

theory

author(s) strand 1

histories of design criticism
Blucher Design Proceedings Dezembro de 2014, Número 5, Volume 1

Robert Lzicar robert.Izicar@hkb.bfh.ch Amanda Unger amanda.unger@gmx.ch Bern University of the Arts

\title{
Designer of the Canon: A Case Study of Swiss Graphic Design Historiography and Tastemaking
}

Switzerland has a notable impact on the development of the historiography of graphic design and design criticism in the second half of the zoth century. This reputation rests on two facts: that it has been the place of publication of some important articles and books and, that a number of Swiss graphic designers were equally prolific as editors and authors. Therefore, publications served as the predominant format for the presentation of approaches to graphic design, through the selection and arrangement of artefacts, which resulted in historical narratives.

The success of the Swiss Style and its widespread successor, the International Typographic Style, fostered an international interest in the historiographical activities by its key representatives such as Karl Gerstner and Josef Müller-Brockmann. Some writers argue that they created narrative structures by "singling out individual designers and works" (Scotford 1991). These narratives are said to serve as a conceptual model for a number of subsequent design histories and lay the foundation for graphic design history as a field of research (Drucker 2009).

Against this backdrop, this paper reconstructs the trajectory of two posters designed by renowned Swiss graphic designer, author and teacher Josef Müller-Brockmann, within selected publications created in Switzerland between 1958 and today. By critically examining the visual and textual narratives accompanying "Schützt das Kind!" (1953) and "Weniger Lärm" (1960), it presents their introduction in and their continuously gaining significance within the canons of the Swiss Style and the International Typographic Style. Furthermore, it traces the impact of Müller-Brockmann's multiple roles as a designer, editor, critic and historian, as well as a tastemaker.

graphic design historiography, tastemaking, Josef Müller-Brockmann, swiss style, international typographic style

\section{Introduction}

From February 10th to June 3rd, 2012 the Museum of Design Zurich presented the extensive exhibition "100 years of Swiss Graphic Design". A central element of the displays was a frieze, which showed one poster for each of the 100 years. This selection included the two posters "Schützt das Kind!" ("Protect the child!") from 1953 and "Weniger Lärm" ("Less noise") from 1960, designed by Josef Müller-Brockmann. Their prominence had already caught our attention during a previous research project recording over 300 graphic design historic publications and exhibitions edited or curated in Switzerland between 1925 and 2013 (http://mappingswissgraphicdesignhistory.ch).

This paper reconstructs a canonization process in the field of graphic design by following 
the trajectory of "Schützt das Kind!" and "Weniger Lärm" through several publications. The objective is to describe the process of writing and disseminating the histories of the Swiss Style and the International Typographic Style, to analyze the development of the visual and textual narratives accompanying the two posters and, finally, to scrutinize Müller-Brockmann's role in this process.

Put simply, a canon can be defined as a mainstream narrative of iconic objects that restricts graphic design history to a number of people and works (Scotford 1991). It is the unintended result of a selection process, but "it has neither developed randomly nor was it institutionalized" (Margolin 1994: 240). More recently, the adoption of methodologies from science and technology studies have led to a shift from the "linear concepts of histories" towards in-depth analyzes of design processes in everyday practice (Wilkins $1992: 4$ ff.), and an increasing focus on networks and relations (Fallan 2010).

Publications can be regarded as "epistemological technologies" (Preziosi 1993) supporting the construction of such narratives (White 1985) and as part of the respective discourse (Foucault 1981). Historiographical examinations of publications have been exemplified in the field of graphic design history (Drucker 2009; McCarthy 2011; Triggs 2009). In our study of publications, we are particularly interested in the use not only of language, but also of images and designs as instruments of historiography and of canonization. Discourse analysis with visual and textual material contributes to the revelation of institutions and practices through which a discourse is formed (Rose 2011).

To select three historically significant examples, we filtered our database for publications, which contain at least one of the two posters. In the following sections these cases are systematically discussed: First we describe the context from which the publication derives. Secondly, we characterize its historical concept and editorial design. Thirdly, we frame the particular context in which the posters are presented. Furthermore, we trace its relationship to previous or following presentations. Lastly, given Müller-Brockmann is a representative of those authoritative Swiss graphic designers, who were also engaged as book designers, editors and authors, we pay particular attention to his role within the canonization of his works, keeping in mind that practitioner-historians are a well-known phenomenon in graphic design history (Margolin 1994; McCarthy 2011; Triggs 2011).

\section{Laying the Foundations: “New Graphic Design”, No. 1 (1958)}

Five years after its initial publication, "Schützt das Kind!" featured in the article "The best recent Swiss Posters 1931-1957" (Neuburg 1958), which appeared in the first issue of "New Graphic Design". The article presents a chronological selection of posters designed in Switzerland between 1931 and 1957, decidedly excluding illustrated and artists' posters. That the article not only illustrates new graphic design methodologies, but also proclaims a modern movement in Switzerland, becomes obvious in the translation of the German title "The best modernly designed Swiss posters [...]" (Neuburg 1958: 52). Thus, the article can be considered as a founding document of a national style, later became famous as the Swiss Style.

The editorial design of the journal follows the same modern paradigms for graphic design as the posters reproduced as part of the article (see Figure 1). "Schützt das Kind!" is arranged in a layout that became typical for the Swiss Style - a square format, structured by a grid with four columns, and surrounded by captions in sans-serif type that declare the reasons for the journal's choice.

Müller-Brockmann's was the initiator and editor of "New Graphic Design", in close cooperation with Richard Paul Lohse, Hans Neuburg - the author of the article - and Carlo Vivarelli. Given their work was included as well, it seems plausible that self- 
publication was part of their editorial concept. Moreover, the introduction to the first issue reveals that the selection of reproduced work represents their intersubjective notion of modern design and thus an attempt at tastemaking (Neuburg et al. 1958).

As the journal was published German, English, and French, the article is likely to disseminated the selection internationally, and have served as reference for following narratives (de Smet 2013). By presenting "Schützt das Kind!" as part of one of the first thoroughly modern histories of Swiss poster design, Müller-Brockmann claims a place in the Swiss Style from the start.

\section{International Career: “A History of Visual Communication” (1971)}

"The new graphic art" (1959) is considered to be one of the first fully fledged surveys on the history of modern graphic design. Eleven years later, Josef Müller-Brockmann publishes "A History of Visual Communication" (1971). Both publications share several examples, as well as the concept of history "as a catalog of examples" selected by "formal principles" (Drucker 2009: 56). Their horizontal layouts emphasize the notion of history as a continuous timeline (see Figure 2). However, modeled after new theoretical concepts of graphic design, introduced at the Ulm School of Design where Müller-Brockmann taught in 1963, "A History of Visual Communication" starts with the beginning of mankind and expands the scope from commercial art to visual communication.

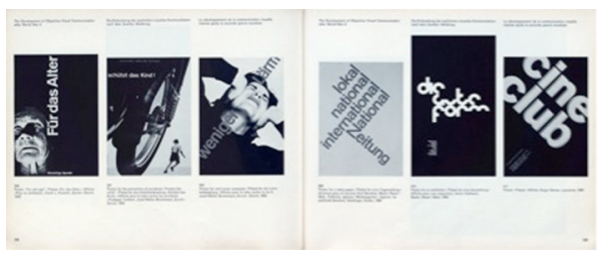

Figure 1.

Single page from "The best recently designed Swiss Posters 1931-1957" published in Neue Grafik Design, Vol. 1, No. 1 (Neuburg 1958), reproduced by the the Graphics Collection of the Museum of Design Zurich

Figure 2. Double-page spread from "A History of Visual Communication" (Müller-Brockmann 1971), reproduced by the authors

"Schützt das Kind!" and "Weniger Lärm" were presented next to each other in the section "The Development of Objective Visual Communication after World War II" (Müller-Brockmann 1971 : 298) (see Figure 2). As the title suggests, the section narrates the development of the International Typographic Style, based on the Swiss Style. This geographical expansion becomes evident by the inclusion of works by graphic designers from various countries, designed with a similar methodology as developed by MüllerBrockmann in the 1950 .

Though this is clearly an understatement, Müller-Brockmann described the creation of the publication as a mere "design opportunity" (Schwemer-Scheddin 1995). However, as author, editor and designer he was equally in charge of the selection of contents whereby 
theme 1

theory

Figure 3.

Book jacket from "Josef Müller-

Brockmann:

Pioneer of Swiss Graphic Design" (Müller 1996), www.goodreads. $\mathrm{com} /$ book/ show/ 647166 . Josef_M_ller_ Brockmann_Des (02.04.2014). strand 1

histories of design criticism

his work appears "for pedagogical purpose" on a regular basis (de Smet 2013: 60). Reinforced by the formal characteristics of the layout and surrounded by classic representative posters of the Swiss Style, he placed "Schützt das Kind!" and "Weniger Lärm" within the founding myth of the International Typographic Style.

Due to the fact that the publication was published in English, German and French (second edition only in English and German) it quickly reached an international audience. MüllerBrockmanns' extensive teaching and lecturing assignments supported its dissemination. Therefore, it not only influenced design practice, but at the same time became a reference for subsequent, widely recognized historical surveys and, thus, a "foundation stone" for the field of research, commonly known as graphic design history (Drucker 2009).

\section{Representative of the Swiss Style: “Josef Müller-Brockmann: Pioneer of Swiss Graphic" (2001)}

"Josef Müller-Brockmann: Pioneer of Swiss Graphic Design" (Müller 1996) is the second, renamed edition of the monographic publication "Josef Müller Brockmann: Gestalter" (Müller 1994). The editor, author and designer Lars Müller published this coffee-table book in German and English. It opens with a biographical text that narrates the professional career of Müller-Brockmann as a coherent development of his design methodologies (Müller 2001 : 11). The text is followed by an image section, presenting selected works designed by Müller-Brockmann like valuable works of art - in large color reproductions, embedded in generous white space.

The dust jacket displays "Schützt das Kind!" and "Weniger Lärm" among twelve other posters against a red background. Its title and design suggest both posters not only as main representatives of Müller-Brockmann's work, but also of Swiss graphic design in general (see Figure 3). This impression is reinforced within the text section, where "Schützt das Kind!" represents a methodological shift and reappears prominently as frontispiece of the color section (Müller 2001 : 40, 42). "Weniger Lärm" is presented including various stages of the design process - a treatment that is reserved to only a few works (Müller 2001 : 146 f.).

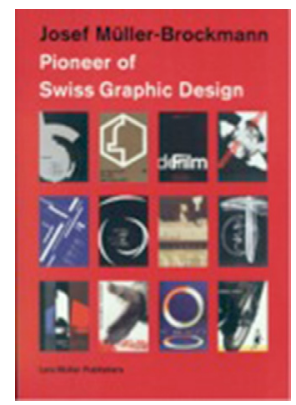

According to the editor Lars Müller, Müller-Brockmann had no say in the formulation of the publication, even though they knew each other personally. However, in the preface the author explicitly appreciates his work and approach (Müller 2001: 6). Apart from the sources stated in the bibliography, the book seems to be mostly based on information from the autobiography "Mein Leben: Spielerischer Ernst und ernsthaftes Spiel" "My life: playful seriousness and serious play") (Müller-Brockmann : 1994).

However, the monographic publication goes one step further: It linguistically and visually positions Müller-Brockmann as a leading figure of the Swiss Style, and declares the 
posters as two of his most important works. Along with the high sales and the global distribution of the book, this narrative has been adopted internationally and both posters became methodological models for the Swiss Style.

\section{Müller-Brockmann as Canonizer and Tastemaker}

To summarize, this paper demonstrates that although canons are formed by the superposition of several narratives, Müller-Brockmanns' roles as graphic design critic and historian created space to promote his work as part of the canons of the Swiss Style and the International Typographic Style, as well as to serve as a tastemaker. The formal methodologies developed by Müller-Brockmann have contributed to the processes of canonization and tastemaking mainly in two respects: By including his own graphic work repeatedly and, by reinforcing them visually, i.e. by way of designing a corresponding layout which reaffirms the reception and classification by the viewer.

Significantly, all analyzed publications have widely been used for teaching and as reference materials. Thus, their editors - all professional graphic designers - could be considered as "shapers of public taste". At the same time, however, practitioner-historians also affect how graphic designers are educated, how they plan their careers, and even more crucially, how they solve problems. We like to think that much more could be discovered about the understanding of graphic design at a certain time, if we look at practitioners' narratives beyond their function as facilitators of style. As a next step, we are planning to apply digital methodologies to examine, for example, which applications of graphic design have been referenced more frequently than others, and suggest a visual design for the resulting relational history.

\section{References}

Drucker, J. (2009) "Philip Meggs and Richard Hollis: Models of Graphic Design History", Design and Culture, vol. 1, no. 1, pp. 51-77.

Fallan, K. (2010) Design History: Understanding Theory and Method, Berg Publishers: Oxford, New York.

Foucault, M. (1981) Archäologie des Wissens, Suhrkamp Verlag: Frankfurt am Main.

Fry, T. (1989) "A Geography of Power: Design History and Marginality", Design Issues, vol. 6, no. 1, pp. 15-30.

Gerstner, K. and Kutter, M. (1959) Die Neue Graphik, Niggli: Teufen.

Hollis, R. (1994) Graphic Design: A Concise History, Thames \& Hudson: London.

Margolin, V. (1994) "Narrative Problems of Graphic Design History", Visible Language, vol. 28, no. 3, pp. 233-43.

McCarthy, S. (2011) "Designer-Authored Histories: Graphic Design at the Goldstein Museum of Design", Design Issues, vol. 27, no. 1, pp. 7-20.

Müller, L. (1994) Josef Müller-Brockmann: Gestalter, Lars Müller Publishers: Baden. Müller, L. (1996) Josef Müller-Brockmann: Pioneer of Swiss Graphic Design, Lars Müller Publishers: Baden.

Müller-Brockmann, J. (1971) Geschichte der visuellen Kommunikation, Niggli: Teufen. Müller-Brockmann, J. (1994) Mein Leben: Spielerischer Ernst und ernsthaftes Spiel, Lars Müller Publishers: Baden.

Neuburg, H. (1958) "The best recently designed Swiss Posters 1931-1957", New Graphic Design, no. 1, pp. 52-61.

Neuburg, H., Lohse, R.P., Müller-Brockmann, J. and Vivarelli, C. (1958) "Introduction", New Graphic Design, no. 1, pp. 2-3.

Preziosi, D. (1993) "Seeing through Art History", in Messer-Davidow, E., Shumway, D.R. and 
Sylvan, D.J. (Eds.), Knowledges: Historical and Critical Studies in Disciplinarity, University of Virginia Press.

Richter, B. (Ed.). (2013) Josef Müller-Brockmann, Poster Collection, Lars Müller Publishers: Baden. Rose, G. (2007) Visual Methodologies an Introduction to Researching with Visual Materials, SAGE: London [etc.].

Schwemer-Scheddin, Y. (1995) "Reputations: Josef Müller-Brockmann", Eye Magazine, vol. 5, no. 19, pp. 10-16.

Scotford, M. (1991) "Is There a Canon of Graphic Design History?", AlGA Design Journal, vol. 9, no. 2 .

De Smet, C. (2013) "The Grid of History", in Richter, B. (Ed.), Josef Müller-Brockmann, Poster Collection, Lars Müller Publishers: Baden, pp. 58-63.

Triggs, T. (2009) "Designing Graphic Design History", Journal of Design History, vol. 22, no. 4, pp. 325-340.

Triggs, T. (2011) "Graphic Design History: Past, Present, and Future”, Design Issues, vol. 27, no. 1 , pp. 3-6.

White, H. (1985) "The Fictions of Factual Representation", Tropics of Discourse: Essays in Cultural Criticism, The Johns Hopkins University Press: Baltimore, pp. 121-134.

Wilkins, B. (1992) "Why is design history so obsessed by appearance? No More Heroes", eye magazine, vol. 2, no. 6, pp. 4-7.

Woodham, J.M. (2005) "Local, National and Global: Redrawing the Design Historical Map", Journal of Design History, vol. 18, no. 3, pp. $257-267$ 